\title{
The psychological impact on family caregivers of children and adolescents with sickle cell anemia
}

\author{
O impacto psicológico em familiares cuidadores de \\ crianças e adolescentes com anemia falciforme
}

\author{
Fernanda Rosalem CAPRINI ${ }^{1}$ iD 0000-0002-6908-2273 \\ Alessandra Brunoro MOTTA $^{1}$ ID 0000-0003-1162-185X
}

\begin{abstract}
Sickle cell anemia represents an aversive context, placing the family in a situation of vulnerability. This study investigated the psychological impact of sickle cell anemia on family caregivers of children and adolescents with this disease. A research with a quantitative approach followed by a survey was carried out, with a non-probabilistic sample of 100 caregivers who answered the instruments for measuring family functioning, disease-related stress, coping, anxiety, and depression. Clinical and sociodemographic characteristics were obtained from medical records and specific protocols. Caregivers of children with late diagnosis presented high disengaged coping scores, and minimum depression; early diagnosis was associated with mild depression. Family functioning domain scores were lower in families with younger children. Regression analyses showed that primary control coping indicates lower depression scores, and involuntary engagement is a predictor of depression/anxiety. This study contributes to the understanding of the relationship between psychological, clinical, and sociodemographic variables in the context of sickle cell anemia.
\end{abstract}

Keywords: Adjustment, psychological; Coping; Psychosocial impact; Stress.

\section{Resumo}

A anemia falciforme representa uma condição aversiva, que pode colocar a familia em situação de vulnerabilidade. Esse estudo investigou o impacto psicológico da anemia falciforme sobre cuidadores familiares de crianças e adolescentes

1 Universidade Federal do Espírito Santo, Centro de Ciências Humanas e Naturais, Programa de Pós-Graduação em Psicologia. Av. Fernando Ferrari, s/n., Prédio Professor Lídio de Souza, Goiabeiras, 29075-910, Vitória, ES, Brasil. Correspondence to: F.R. CAPRINI. E-mail: <fernandacaprini@gmail.com>.

Article based on the dissertation of F.R. CAPRINI, entitled "Avaliação e intervenção psicossocial em cuidadores familiares de crianças com anemia falciforme". Universidade Federal do Espírito Santo, 2019.

Support: Coordenação de Aperfeiçoamento de Pessoal de Nivel Superior.

How to cite this article

Caprini, F. R., \& Motta, A. B. (2021). The psychological impact on family caregivers of children and adolescents with sickle cell anemia. Estudos de Psicologia (Campinas), 38, e190168. https://doi.org/10.1590/1982-0275202138e190168
} 
com a doença. Realizou-se uma pesquisa de abordagem quantitativa e de levantamento, com amostra não probabilistica de 100 cuidadores, os quais responderam aos instrumentos sobre funcionamento familiar, estresse, coping, ansiedade e depressão. Características clínicas e sociodemográficas foram obtidas em prontuários médicos e protocolos específicos. Cuidadores de crianças com diagnóstico tardio apresentaram maior escore de coping desengajado e depressão mínima; o diagnóstico precoce se associou com depressão leve. Escores do funcionamento familiar foram mais baixos em familias com crianças menores. Análises de regressão mostraram que coping de controle primário diminui escores de depressão e que engajamento involuntário prediz aumento de depressão/ansiedade. Esse estudo contribui para a compreensão da relação entre variáveis psicológicas, clínicas e sociodemográficas no contexto da anemia falciforme.

Palavras-chave: Ajustamento psicológico; Enfrentamento; Impacto psicossocial, Estresse.

Sickle Cell Anemia is one of the most common inherited diseases, and the one with the most frequent morbidity and mortality in the world, especially in developing countries (McGann, 2014). In Brazil, studies suggest that the origin of the disease occurred with the immigration of black African people to be enslaved, predominantly affecting black and brown people (Ministério da Saúde, 2015; Reis et al., 2018).

Data from the Ministério da Saúde (2015) reveal that about 3,000 babies are born with sickle cell anemia in the country each year and an average of 200,000 have the sickle cell trait. More specifically, the state of Espirito Santo holds the seventh place with the highest number of children diagnosed with sickle cell anemia, indicating 1:1800 cases (Ministério da Saúde, 2015).

Despite having a varied symptomatology, a significant number of patients have chronic and severe forms of the disease, characterized by vaso-occlusive crises (Sabino \& Gradella, 2016) caused by the accumulation of sickle cells and the consequent obstruction of blood vessels, leading to ischemia of the tissues (Ministério da Saúde, 2015). Such crises can be considered as the most poignant symptom of the disease, as they can occur unexpectedly and directly impact the patient's quality of life (Miranda \& Brito, 2016).

In this sense, both the child and the adolescent affected by the disease, as well as their family caregivers, are faced with a situation marked by a chronic stress linked to the disease, which extends throughout the treatment and permeates their daily lives (Figueiró \& Ribeiro, 2017; Gomes et al., 2019; Jesus, Konstantyner, Lobo, \& Braga, 2018; Rodrigues, Araújo, \& Melo, 2010; Santos, Damião, Fonseca, Rodrigues, \& Aguiar, 2019); being indicated that intervention proposals are directed both to the child (Campelo et al., 2018; Oliveira, Enumo, \& Paula, 2017) and to the family (Caprini, 2019; Figueiredo, Moreira, Mota, Oliveira, \& Gomes, 2019).

This study considers disease-related parenting stress, which is defined as an imbalance between the child's health care demands and the parents' assessment of their available resources (Abidin, 1992). Conducted by Thompson and colleagues, a number of studies concluded that sickle cell anemia is a potential stressor, and patients and their families have to deal with it (Thompson, Gil, Burbach, Keith, \& Kinney, 1993). As in other chronic conditions, stressors related to sickle cell anemia have the characteristic of uncontrollability (Prussien et al., 2018), which can be translated into the occurrence of painful episodes, given that the cure is rare and the restrictions imposed by the disease itself (Compas, Jaser, Dunn, \& Rodriguez, 2012).

Uncertainties related to the experience of dealing with a chronic disease in childhood and adolescence have been predictors of suffering, anxiety and depression for parents (Monti et at., 2017; Pai et al., 2007). Anxiety and depression are understood as emotional problems, with different symptoms, with depression being understood as a clinical disorder characterized by depressed mood; anxiety, on the other hand, is characterized by the presence of excessive and uncontrollable concerns about different aspects of life (Cunha, 2001).

Findings about predictors of anxiety and depression in chronic disease are relevant, since depressive symptoms in parents can limit their resources for teaching coping strategies for the child to effectively deal with chronic disease (Monti et al., 2017). In the context of chronic diseases, some findings have shown that mothers with depression are less able to suggest adaptive coping strategies to their children (Monti et al.,

2 2017); and that parents in this emotional context may find it more difficult to assist their children in managing 
disease-related stress (Alves, Guirardello, \& Kurashima, 2013), may be less responsive to their children's needs and more disconnected with them (Lovejoy, Graczyk, O'Hare, \& Neuman, 2000). It is understood, therefore, that emotional variables, such as anxiety and depression of parents or legal guardians, can negatively interfere in the development of children and adolescents affected with a chronic disease, such as sickle cell anemia (Kazak et al., 2003).

Regarding childhood cancer, the depressive symptoms of parents are a strong influence on the child's coping behaviors (Monti et al., 2017). In addition, parenting distress is strongly associated with the child's poor emotional functioning (Pai et al., 2007). Thus, scientific research has further indicated the power of predicting emotional variables and parental coping in the development of their children (Monti et al., 2017), showing that it is extremely important that these variables are studied so that future interventions are implemented (Shashine, Badr, Karam, \& Abboud, 2014).

In the context of sickle cell anemia, some theoretical models have guided research in order to understand the relationship between the disease and its developmental results, in terms of psychological adjustment of patients and their parents (Brown et al., 2000; Thompson et al., 1993). The risk and resistance model of Wallander et al. (1989) considers risk and resistance factors as predictors of the psychological adjustment of children with chronic diseases. Among the risk factors would be characteristics of the disease, such as the degree of disability, its severity and visibility; such factors would have a different impact, depending on the resistance factors that will act as moderators and/or mediators. The resistance factors included in the model refer to the person's characteristics, ecological and social context, and management of stress (Brown et al., 2000). In the study by Brown et al. (2000), the results confirmed the associations between the coping of the primary caregiver and the psychological adjustment of the child and, also, of the caregiver, in relation to the disease. The conceptual stress and coping model by Thompson et al. (1993) are also an alternative. This model adopts the theoretical perspective of ecological systems to understand the relationship between the disease and psychological adjustment, understanding that this is a function of the transactions between the variables related to the disease and demographic characteristics (sex, age and socioeconomic level) and the adaptation process, which acts as a mediator. This model has been applied in the context of sickle cell anemia, in studies focusing on the psychological adjustment of mothers (Thompson et al., 1993).

Adopting a model based on the perceived controllability of the stressor, Compas et al. (2012) investigated the relationship between the adaptation process (coping) and the psychological adjustment of patients and caregivers in the context of chronic diseases, such as cancer (Rodriguez et al., 2016). According to this model, coping can be defined as a set of conscious and volitional efforts that regulate emotion, cognition, behavior, physiology, and the environment in response to stressful events or circumstances (Compas et al., 2012). Coping is organized into three different groups, namely: (a) primary control coping, which includes behavioral and cognitive strategies that act directly in altering the stressor or in the emotional response to it; (b) secondary control coping, which includes efforts to adapt to the demands of the stressor, through distraction, acceptance, and positive thinking strategies; and (c) disengagement, which includes strategies to remove stressors, such as avoidance and wishful thinking. In the study by Rodriguez et al. (2016), high levels of primary and secondary control coping were predictors of less depressive symptoms in the primary caregivers of children with cancer, confirming the model's ability to explain the relationship between the variables related to the adaptation process to the child's disease.

Based on findings in the literature that suggest the use of theoretical models to guide studies on the relationships between the disease, the adaptation process and developmental results, in terms of the psychological adjustment of patients and their parents, this study aimed to investigate the psychological impact of sickle cell anemia on family caregivers of children and adolescents with the disease. Specifically, there was a relationship between variables related to the adaptation process of family caregivers to the child's disease 
(stress, coping and family functioning), psychological variables of family caregivers (anxiety and depression), and clinical and sociodemographic variables.

To guide the study's hypotheses, a conceptual model was adopted based on the perceived controllability of the stressor (Compas et al., 2012), since no studies were found with caregivers of children and adolescents with sickle cell anemia. Based on this model, two hypotheses were established: (a) the clinical and sociodemographic characteristics of children and adolescents are related to indicators of parental anxiety and depression, stress, coping, and family functioning; and (b) the variables of the adaptation process (stress, coping and family functioning) will act as predictors of indicators of anxiety and depression for family caregivers.

\section{Method}

\section{Participants}

This is a research with a quantitative approach followed by a survey and a non-probabilistic sample. The study data were obtained from the composition of a convenience sample of 100 family caregivers of children and adolescents diagnosed with sickle cell anemia. Participants were recruited at the Hospital Estadual Infantil Nossa Senhora da Glória (Nossa Senhora da Glória State Hospital for Children), which is a reference for the treatment of children and adolescents with sickle cell anemia in the state of Espírito Santo, linked to the Sistema Único de Saúde (Brazilian Unified Health System). The sample included all family caregivers whose children and adolescents were being treated at the hospital, and who were primarily responsible for the child or adolescent. Caregivers who were in the emergency room were excluded from the study, considering the difficulty of contacting patients in this place. In addition, the presence of another chronic disease was also an exclusion criterion for the sample.

\section{Instruments}

The research used the instruments described below.

Protocol for recording the clinical characteristics of the child: a form, specially designed to record the child's clinical data (time of diagnosis, pain crises, comorbidities, treatment protocol, medications). This form was filled out by the researcher, after consulting the child's medical records.

Critério de Classificação Econômica do Brasil (CCEB, Brazilian Economic Classification Criterion): a questionnaire developed by the Associação Nacional de Empresas de Pesquisa (National Association of Research Companies) (Associação Nacional de Empresas de Pesquisa, 2013), capable of classifying families into different economic classes, which vary from Class A, with greater purchasing power, up to Class D, whose purchasing power is less. The CCEB has 15 items and was answered by the caregiver in an interview.

Responses to Stress Questionnaires (RSQ) - Version for parents of children/adolescents with sickle cell anemia (Connor-Smith, Compas, Wadsworth, Thomsen, \& Saltzman, 2000): The RSQ aims to measure coping and involuntary stress responses, using items distributed in five factors, three of which characterize types of coping: (a) primary control coping; (b) secondary control coping; and (c) disengaged coping; and two characterize responses to stress: (d) involuntary engagement; and (e) involuntary disengagement. The instrument has 70 items and the answers are provided on a Likert Scale, ranging from never to very often. The instrument's internal consistency was considered acceptable for the five factors, ranging from 0.79 to 0.84 between the domains (Wadsworth, Rieckmann, Benson, \& Compas, 2004). The RSQ has different versions, for various conditions of chronic diseases, including sickle cell anemia. For this study, the 
coping self-report questionnaire for parents about their child's disease. The version for sickle cell anemia had a linguistic adaptation carried out (Caprini, 2019), after obtaining authorization from its authors.

Inventário de Percepção do Suporte Familiar (IPSF, Family Support Perception Inventory) (Baptista, 2007): The IPSF assesses the family environment and its functioning, in terms of affection, autonomy, and adaptation among members. According to the author, family functioning mostly reflects the proposal of family support in several dimensions, such as clarity of communication, proximity versus distance between members, organization of the group in specific contexts, affective connection, family roles, and beliefs about the representation of these roles (Baptista, 2007).

It consists of 42 items grouped in the following domains: (a) affective-consistent, with 21 items, which cover verbal and non-verbal expression of affection, the interest and closeness between family members, aspects of their communication and interaction, embracing support, respect, empathy, setting rules within the family, and problem solving skills; (b) family adaptation, with 13 items, which address negative valued feelings and behaviors related to the family. These include anger, isolation, shame, competition between members, blaming, among others that overlap with the most proactive interrelationships; and (c) and autonomy, with eight items, which address relationships of trust between members, and the freedom to express themselves with autonomy (Baptista, 2007). The IPSF is answered on a three-point Likert Scale, ranging from never or almost never to always or almost always. The analysis of the scale indicates the presence of problems when participants have low scores in the domains, as well as in the general assessment. The IPSF presents satisfactory indicators of internal consistency ( $\alpha=0.93$, varying from 0.78 to 0.91 , for each of the three domains assessed).

Pediatric Inventory for Parents (PIP) - (Streisand, Braniecki, Tercyak, \& Kazak, 2001), Brazilian version (Alves et al., 2013): An instrument designed to assess, in the adult population, signs of stress related to the presence of a chronic disease in their children. It was answered by the caregivers and consists of 42 items, distributed in four domains: communication (nine items), medical care (eight items), emotional function (15 items) (Brazilian translation of the term "distress") and family function (10 items). The communication domain involves the difficulties in talking or understanding the health care team and their instructions, talking to the child, discussing and disagreeing with the health care team, for example. The medical care domain involves taking the child to the hospital, making treatment decisions, following up on treatment, and maintaining childcare. The emotional function and family function domains involve emotional variables, such as changes in mood and anxiety, and family variables, such as having financial problems, being away from the family and seeing changes in their marital relationship. The items are assessed regarding the frequency of events in the last week and the difficulty presented before these events. A five-point Likert measurement scale was used, where $1=$ nothing and $5=$ very much. The values of the PIP - Brazilian version scores, can vary from 42 to 210 for the general scale. The specific domains have a range of variation according to the number of items (communication $=9$ to 36 , medical care $=8$ to 32 , emotional function $=15$ to 60 , and family function $=10$ to 40 ). The higher the score on the general scale and the subscales, the higher the stress level. The instrument has good indicators of internal consistency (Cronbach's alpha $=0.70)$.

Beck Depression Inventory (BDI) - (Cunha, 2001): It is a depression self-assessment instrument, through 21 items that include symptoms and attitudes, such as sadness, pessimism, feeling of failure, lack of satisfaction, feeling guilty, feeling of punishment, self-deprecation, self-accusations, suicidal ideas, crying crises, irritability, social withdrawal, indecision, distortion of body image, and weight loss (Cunha, 2001). Each of the categories presents alternatives that express the levels of severity of symptoms, composing a four-point Likert Scale $(0=$ absence of depressive symptoms and $3=$ presence of more intense symptoms). The sum of the scores of each participant is classified, according to the manual, as 0 to 11 points = minimum; 12 to 19 = light; 20 to 35 points = moderate; and 36 to 63 points = severe (Cunha, 2001). It is a measure widely used in research and in the clinic, both nationally and internationally. It refers to high reliability and internal consistency (Cronbach's alpha coefficient $=0.86)$, being easy and quick to apply (Cunha, 2001). 
Beck's Anxiety Inventory (BAI) - (Cunha, 2001): Instrument developed by Beck, with the objective of assessing symptoms of anxiety in adults. The scale is composed of 21 items that describe symptoms that are common to the symptoms of anxiety and their intensity. The instrument is presented on a four-point Likert Scale, ranging from No to Severely, for the presence and intensity of the symptom. The analysis of the responses is made by adding the scores of each participant and later classification, according to the manual itself: 0 to 10 points $=$ minimum level of anxiety; 11 to 19 points = light level; 20 to 30 points = moderate level; and 31 to 63 points = severe level. The instrument indicates good internal consistency $(\alpha=0.92)$ and good test-retest reliability, with a one-week difference $(r=0.75)$.

\section{Procedures}

After the composition of the sample, with the identification of the participants' hospital records, an interview was conducted with each participant in order to obtain their consent to participate in the research, in accordance with Resolution $n^{\circ}$ 466/2012 of the Comissão Nacional de Ética em Pesquisa (National Research Ethics Commission) / National Health Council / Ministry of Health, the Certificado de Apresentação para Apreciação Ética (CAAE, Presentation Certificate for Ethical Appreciation) protocol n 64685517.2 .0000 .5542 , and the approval of the local Ethics Committee. After this stage, data collection was carried out - between April and December 2017 -, through the application of instruments to investigate socio-demographic variables (CCEB), the adaptation process to the disease (PIP, RSQ, and IPSF) and emotional indicators (BDI and BAI).

\section{Data analysis}

Data analysis included, first, the correction of the instruments based on the authors' guidelines and, later, the submission to the descriptive statistical analysis (frequency, proportion, mean, and standard deviation). This analysis allowed to characterize the sample in terms of sociodemographic variables (CCEB), the adaptation process to the disease (PIP, RSQ, and IPSF), emotional indicators (BDI and BAI) and clinical characteristics of patients.

Inferential statistical analysis was used to verify significant differences between the characteristics of the chronic disease in children and adolescents (time of diagnosis) in relation to the study variables. For this, the comparison between the diagnostic groups was performed using Mann-Whitney tests (numerical variables) or Chi-Square tests (categorical variables). Nonparametric analyzes were used because most of the studied variables did not have a normal distribution.

The Spearman coefficient was used to assess the correlation between children's age and the scores of the studied instruments. To compare children's ages among the categories of the instruments, the Kruskal-Wallis test was used, followed by the Dunn multiple comparison test. This coefficient was also used to assess the correlation between the scores of all instruments. Linear regression models were used to assess the predictive power of the RSQ over the BDI and the BAI. The adopted level of significance was $5 \%$.

\section{Results}

\section{Sociodemographic characterization of participants and clinical characterization of children and adolescents}

A total of 100 caregivers of children and adolescents diagnosed with sickle cell anemia participated in 6 the study. Considering that the participants were interviewed in an outpatient setting, some of the collections 
had to be interrupted for the child's medical procedure, that is, not all instruments could be applied to the total sample. Thus, in the BDI $(n=94)$, the BAI $(n=93)$ and the IPSF $(n=93)$ instruments, the sample number was lower. For the other instruments, the sample was composed of 100 participants. Most of these participants were mothers $(80.0 \%)$, followed by fathers (13.0\%) (Table 1). The children's age ranged from 0 to 18 years $(M=8.9$ years; $S D=5.4$ years), with the majority of them being boys $(53.0 \%)$.

Regarding the patients, most children and adolescents were diagnosed at birth, in neonatal screening (heel prick test) $(84.0 \%)$, followed by those who received late diagnosis (15.0\%). One child was diagnosed during pregnancy $(1.0 \%)$.

\section{Descriptive data on the psychological impact of sickle cell anemia on caregivers}

Regarding the emotional variables of the research participants, the measure of disease-related stress (measured by the PIP) indicated total averages of 114.9 (SD = 32.5) for frequency, and 90.7 (SD = 33.3) for difficulty. With regard to the domains investigated by the instrument, the emotional function presented in the face of the chronic disease of the child/adolescent obtained the highest averages both in the frequency $(M=43.1 ; S D=13.8)$ with which it occurs, and in the difficulty to be faced $(M=39.6 ; S D=15.5)$. The domain that presented the lowest mean scores was communication (frequency with $M=21.4 ; S D=7.4$ and difficulty, with $M=14.3 ; S D=5.9$ ).

Table 2 also describes the coping data, assessed through the RSQ, which indicated higher averages in the secondary control coping categories $(M=0.25 ; S D=0.04)$ and involuntary engagement responses $(M=0,25 ; S D=0.05)$. The lowest index was presented in the involuntary responses of disengaged stress category $(M=0.16 ; S D=0.03)$.

The IPSF instrument assessed how much people perceive family relationships in terms of affectivity, autonomy, and adaptation among members. Table 2 shows that the highest averages were obtained

Table 1

Sociodemographic indicators of caregivers and clinical variables of children/adolescents $(N=100)$

\begin{tabular}{|c|c|c|}
\hline Sociodemographic variables of caregivers & $F$ & $\%$ \\
\hline Mother & 80 & 80.0 \\
\hline Father & 13 & 13.0 \\
\hline Others (grandparents, aunts, stepmothers) & 7 & 7.0 \\
\hline \multicolumn{3}{|l|}{ Social class, measured by the CCEB } \\
\hline B2 & 3 & 3.0 \\
\hline C1 & 6 & 6.0 \\
\hline C2 & 41 & 41.0 \\
\hline $\mathrm{D}-\mathrm{E}$ & 50 & 50.0 \\
\hline \multicolumn{3}{|l|}{ Clinical variables of children/adolescents } \\
\hline \multicolumn{3}{|l|}{ Presence of pain crises ( $n=99$ ) } \\
\hline Yes & 68 & 68.7 \\
\hline No & 31 & 31.3 \\
\hline \multicolumn{3}{|l|}{ Presence of comorbidity } \\
\hline Yes & 12 & 12.0 \\
\hline No & 88 & 88.0 \\
\hline \multicolumn{3}{|l|}{ Type of treatment } \\
\hline Transfusion & 1 & 1.0 \\
\hline Means of medication & 69 & 69.0 \\
\hline Medication and transfusion & 22 & 22.0 \\
\hline Medication, transfusion, and bloodletting & 6 & 6.0 \\
\hline None & 2 & 2.0 \\
\hline
\end{tabular}

Note: CCEB: Critério de Classificação Econômica do Brasil (Brazilian Economic Classification Criterion); F: Frequency.

B2, C1, C2 D-E: Social Class, measured by the CCEB. B2: R\$5.363,19 (Middle-income); C1: R\$2.965,69 (Middle-income); C2: R\$1.691,44 (Middle-income); D-E: R\$708,19 (Middle-income). 
Table 2

Descriptive data on stress (PIP), coping (RSQ) and family functioning (IPSF) ( $N=100)$

\begin{tabular}{|c|c|c|c|c|}
\hline \multirow{2}{*}{$\begin{array}{l}\text { Variables related to the disease adaptation process } \\
\text { Stress }\end{array}$} & \multicolumn{2}{|c|}{ Mean } & \multicolumn{2}{|c|}{ Standard Deviation } \\
\hline & Frequency & Difficulty & Frequency & Difficulty \\
\hline $\begin{array}{l}\text { Communication } \\
\text { Medical care } \\
\text { Emotional function } \\
\text { Family function } \\
\text { Total } \\
\end{array}$ & $\begin{array}{r}21.4 \\
25.4 \\
43.1 \\
25.1 \\
114.9 \\
\end{array}$ & $\begin{array}{l}14.3 \\
14.5 \\
39.6 \\
22.5 \\
90.7\end{array}$ & $\begin{array}{l} \pm 7.4 \\
\pm 7.1 \\
\pm 13.8 \\
\pm 8.8 \\
\pm 32.5\end{array}$ & $\begin{array}{l} \pm 5.9 \\
\pm 6.9 \\
\pm 15.5 \\
\pm 9.4 \\
\pm 33.3\end{array}$ \\
\hline Coping & \multicolumn{2}{|c|}{ Mean } & \multicolumn{2}{|c|}{ Standard Deviation } \\
\hline $\begin{array}{l}\text { Primary control coping } \\
\text { Secondary control coping } \\
\text { Disengaged coping } \\
\text { Involuntary engagement } \\
\text { Involuntary disengagement }\end{array}$ & & & & \\
\hline Family functioning $(n=93)$ & \multicolumn{2}{|c|}{ Mean } & \multicolumn{2}{|c|}{ Standard Deviation } \\
\hline $\begin{array}{l}\text { Affective-consistent } \\
\text { Adaptation } \\
\text { Autonomy }\end{array}$ & \multicolumn{2}{|c|}{$\begin{array}{l}72.5 \\
59.2\end{array}$} & \multicolumn{2}{|c|}{$\begin{array}{l}25.7 \\
27.9\end{array}$} \\
\hline
\end{tabular}

Note: IPSF: Inventário de Percepção do Suporte Familiar (Family Support Perception Inventory); PIP: Pediatric Inventory for Parents; RSQ: Responses to Stress Questionnaires.

in the Affective-consistent domain $(M=72.5 ; S D=25.7)$, followed by the Autonomy domain $(M=63.8$; $S D=28.4)$ and Adaptation $(M=59.2 ; S D=27.9)$.

Regarding indicators of anxiety and depression, most caregivers had Minimum (54.0\%) and Light (27.0\%) indicators of depression, followed by Moderate (16.0\%) and Severe (2.1\%). The same distribution was observed in the indicators of anxiety: Minimum (54.0\%), Light (20.4\%), Moderate (12.9\%) and Severe $(7.5 \%)$.

\section{Inferential analyzes of the relationships between the study variables}

A correlation analysis was performed between the time of diagnosis (at birth or later in childhood) and the psychological variables of the caregivers (BDI, BAI, PIP, RSQ, and IPSF), using the Mann-Whitney or Chi-Square test. There was a significant difference between the two groups for Disengaged Coping, measured through the RSQ instrument $\left(p_{\text {value }}=0.0030\right)$. The group with a late diagnosis had higher values for Disengaged Coping (median $=0.19$ ) than the group with a diagnosis at birth (median $=0.17$ ). There was also a significant association between the $\mathrm{BDI}$ and time to diagnosis ( $\left.p_{\text {value }}=0.0304\right)$. Late diagnosis is more associated with minimum BDI (69.2\%) and diagnosis at birth with low BDI scores (31.3\%).

When comparing the age of children among the categories of the classified variables (Table 3), a significant difference in ages among the categories of the IPSF Adaptation domain $\left(p_{\text {value }}=0.021\right)$ and also of the total IPSF ( $p_{\text {value }}=0.016$ ) domain can be observed. The children whose family caregivers were classified in the Low category of the Adaptation domain were younger than children whose parents were classified in the Medium low and Medium high categories. In other words, the perception of adaptation in family functioning is lower in families with younger children. This was also observed in relation to the total family functioning score, in which children and adolescents of caregivers in the Low classification were younger than those whose parents were classified in the Medium low, Medium high and High categories. It is verified, therefore, that families with younger children, indicate lower indices in the perception of family functioning.

Table 4 presents the results of applying simple linear regression models to assess the predictive power of the coping domains (measured by the RSQ) in the psychological adjustment of caregivers, obtained from 
Table 3

Comparison between the family functioning domains, measured by the IPSF, in the different age groups of children $(n=93)$

\begin{tabular}{|c|c|c|c|c|c|c|c|c|}
\hline Family functioning & Classification & $N$ & Mean age & Standard Deviation & Minimum & Median & Maximum & $p_{\text {value }}$ \\
\hline Adaptation & $\begin{array}{l}\text { Low } \\
\text { Medium-Low } \\
\text { Medium-High } \\
\text { High }\end{array}$ & $\begin{array}{l}13 \\
11 \\
27 \\
42\end{array}$ & $\begin{array}{r}4.9 \\
9.8 \\
10.6 \\
8.4\end{array}$ & $\begin{array}{l}5.3 \\
5.3 \\
4.3 \\
5.3\end{array}$ & $\begin{array}{l}0.0 \\
0.0 \\
0.0 \\
0.0\end{array}$ & $\begin{array}{r}2.0 \\
9.0 \\
12.0 \\
8.0\end{array}$ & $\begin{array}{l}15.0 \\
17.0 \\
18.0 \\
17.0\end{array}$ & 0.021 \\
\hline Autonomy & $\begin{array}{l}\text { Low } \\
\text { Medium-Low } \\
\text { Medium-High } \\
\text { High }\end{array}$ & $\begin{array}{l}11 \\
14 \\
27 \\
41\end{array}$ & $\begin{array}{l}8.6 \\
9.1 \\
8.7 \\
8.6\end{array}$ & $\begin{array}{l}6.2 \\
5.4 \\
5.4 \\
5.0\end{array}$ & $\begin{array}{l}0.0 \\
1.0 \\
0.0 \\
0.0\end{array}$ & $\begin{array}{r}11.0 \\
9.5 \\
9.0 \\
9.0\end{array}$ & $\begin{array}{l}18.0 \\
17.0 \\
18.0 \\
17.0\end{array}$ & 0.992 \\
\hline Affective-consistent & $\begin{array}{l}\text { Low } \\
\text { Medium-Low } \\
\text { Medium-High } \\
\text { High }\end{array}$ & $\begin{array}{c}8 \\
11 \\
14 \\
60\end{array}$ & $\begin{array}{r}4.0 \\
7.8 \\
10.1 \\
9.2\end{array}$ & $\begin{array}{l}5.1 \\
6.2 \\
4.4 \\
5.0\end{array}$ & $\begin{array}{l}0.0 \\
0.0 \\
4.0 \\
0.0\end{array}$ & $\begin{array}{r}2.0 \\
9.0 \\
9.0 \\
10.0\end{array}$ & $\begin{array}{l}15.0 \\
17.0 \\
18.0 \\
18.0\end{array}$ & 0.070 \\
\hline Total IPSF & $\begin{array}{l}\text { Low } \\
\text { Medium-Low } \\
\text { Medium-High } \\
\text { High }\end{array}$ & $\begin{array}{l}11 \\
10 \\
17 \\
55\end{array}$ & $\begin{array}{r}4.0 \\
10.9 \\
8.5 \\
9.3 \\
\end{array}$ & $\begin{array}{l}4.7 \\
5.0 \\
5.2 \\
5.0\end{array}$ & $\begin{array}{l}0.0 \\
1.0 \\
0.0 \\
0.0\end{array}$ & $\begin{array}{r}2.0 \\
10.5 \\
8.0 \\
10.0\end{array}$ & $\begin{array}{l}15.0 \\
18.0 \\
18.0 \\
17.0\end{array}$ & 0.016 \\
\hline
\end{tabular}

Note: Values in bold highlight the factor for which the item was considered representative. Test used: Kruskal-Wallis test. IPSF: Inventário de Percepção do Suporte Familiar (Family Support Perception Inventory).

Table 4

Simple linear regression for each of the RSQ domains in the BDI and the BAI

\begin{tabular}{|c|c|c|c|c|c|c|c|}
\hline \multirow{2}{*}{ Instrument } & \multirow{2}{*}{ RSQ } & \multicolumn{3}{|c|}{ Intercept } & \multicolumn{3}{|c|}{ Coefficient } \\
\hline & & Estimate & Standard error & $p_{\text {value }}$ & Estimate & Standard error & $p_{\text {value }}$ \\
\hline \multirow{5}{*}{ BDI } & Primary coping & 27.0 & 4.1 & $<0.001$ & -88.4 & 23.5 & $<0.001$ \\
\hline & Secondary coping & 37.4 & 4.8 & $<0.001$ & -103.3 & 18.9 & $<0.001$ \\
\hline & Disengaged coping & 16.8 & 6.6 & 0.014 & -29.2 & 38.2 & 0.447 \\
\hline & Involuntary engagement & -11.6 & 3.9 & 0.004 & 92.5 & 15.3 & $<0.001$ \\
\hline & Involuntary disengagement & -3.0 & 4.6 & 0.521 & 95.9 & 29.4 & 0.002 \\
\hline \multirow{5}{*}{ BAl } & Primary coping & 36.1 & 6.5 & $<0.001$ & -139.9 & 36.6 & $<0.001$ \\
\hline & Secondary coping & 49.1 & 7.6 & $<0.001$ & -149.1 & 30.1 & $<0.001$ \\
\hline & Disengaged coping & 17.0 & 10.3 & 0.104 & -29.7 & 59.4 & 0.618 \\
\hline & Involuntary engagement & -23.6 & 6.2 & $<0.001$ & 141.3 & 24.4 & $<0.001$ \\
\hline & Involuntary disengagement & -8.0 & 7.3 & 0.273 & 129.6 & 46.4 & 0.006 \\
\hline
\end{tabular}

Note: Values in bold highlight the factor for which the item was considered representative. BAI: Beck's Anxiety Inventory; BDI: Beck Depression Inventory; RSQ: Responses to Stress Questionnaires.

the indicators of depression (measured by the BDI) and anxiety (measured by the BAI). This table shows that all domains, except for disengaged coping, are individually associated with the BDI and the BAI. To interpret this table, it is necessary to consider the example with primary coping in the BDI. The increase of one primary coping unit reduces, on average, 88.4 points of the BDI, that is, the increase of 0.1 in primary coping reduces the BDI score by 8.84 .

Multiple linear regression models, with stepwise variable selection criteria, were adjusted to the data and, for both $\mathrm{BDI}$ and the $\mathrm{BAl}$, the variable that proved to be the most important for predicting the values of the two scales was Involuntary Engagement, with R2 equal to $30.2 \%$ and $28.8 \%$ for the BDI and the $\mathrm{BAI}$, respectively. The R2 values indicate that $30.2 \%$ of the BDI variability can be explained by Involuntary Engagement, and $\mathbf{2 8 . 8 \%}$ of the BAI variability can be explained by Involuntary Engagement. To calculate the change in the BDI and the BAI, from Involuntary Engagement, the results in Table 4 can be used. So, the 0.05 increase in Involuntary Engagement increases, on average, $4.6(0.05 * 92.5)$ in the BDI score and 7.1 $(0.05 * 141.3)$ in the BAl score. It can be seen, therefore, that the use of primary control coping strategies decreases depression scores for the investigated population. The use of involuntary engagement predicts the increase in the depression and anxiety levels of the caregiver. 


\section{Discussion}

This study aimed to investigate the psychological impact of sickle cell anemia on caregivers of children and adolescents with this disease. Specifically, there was a relationship between variables related to the adaptation process of family caregivers to the child's disease (stress, coping and family functioning), psychological variables of family caregivers (anxiety and depression) and clinical and sociodemographic variables.

The sample characterization findings allowed to verify the predominance of mothers as primary caregivers of children and adolescents with sickle cell anemia, which has been observed in several pediatric contexts (Alves et al., 2013), in addition to sickle cell anemia (Figueiró \& Ribeiro, 2017). The burden of care falls on the maternal figure, which brings other consequences for family functioning, such as financial problems, which can get worse with the mother's exclusion from the labor market (Figueiró \& Ribeiro, 2017). It is likely that the income limitations observed in the participating families have been affected by this condition, adding to other socioeconomic issues related to the population of patients with sickle cell anemia. It refers to the fact that this population is located mostly in the poorest layers of the population, in addition to affecting, predominantly, the black and brown population (Ministério da Saúde, 2015). In this context of economic and social vulnerability, families of children with sickle cell anemia need to deal with prejudice in health care service, with the invisibility of the disease and with difficulties in accessing treatment (Figueiró \& Ribeiro, 2017), which constitutes a psychosocial risk for that population.

In the same direction, the fact that late diagnosis is still present (15\% of the sample) is highlighted, even in the presence of public policies aimed at detecting the disease at the time of birth (Ministério da Saúde, 2015). Psychosocial factors can contribute to explain this data, adding the psychosocial risk to the biological risk represented by the disease. In terms of the disease, this percentage of late diagnosis represents children who were not treated early, whose caregivers or doctors failed to prevent infectious complications, to receive appropriate immunizations and safe transfusions (Sarat et al., 2019). This situation may be associated with a less adaptive outcome to the disease, in terms of the coping of caregivers, since, for this sample, a late diagnosis is associated with higher levels of disengaged coping strategies, in which the caregiver uses his or her efforts to get away from the stressor (Rodriguez et al., 2016).

Still in relation to coping, this predominance of disengaged coping in caregivers of younger children differed from the group as a whole. This is because there was a predominance in the use of secondary control coping strategies, which includes efforts to adapt to the demands of the stressor, through strategies of distraction, acceptance, and positive thinking, as has been observed in samples of caregivers of children with chronic diseases (Rodriguez et al., 2016).

Regarding the age of children, it was found that families with younger children achieved lower family functioning perception scores. The younger the child, the closer the family is to the experience of diagnosis, especially when it is given right after birth. The literature is solid in the statement that the period of diagnosis of a chronic disease has a significant impact on the family, which can lead to difficulties in adapting family functioning (Streisand et al., 2001). In addition to problems in family functioning, stress reactions, anxiety and depression, they can also be observed and, depending on the way in which parents deal with the demands of this stage, it will be possible to verify adaptation processes over time (Streisand et al., 2001).

In this study, stress reactions were observed in the PIP emotional function domain, indicating the sickle cell anemia experience as a stressor. This data reinforces the presence of suffering and anguish regarding the treatment and diagnosis of a chronic disease in children (Alves et al., 2013). Emotional function was also more affected in the context of childhood cancer, with high frequency and difficulty averages, indicating that there is a compromise in the emotional state of parents facing a child's chronic disease. Attention to 
these stress reactions is important, as they can compromise the care that parents provide to their child, in addition to interfering in their family role, in their quality of life, and in their relationship with the health care team (Alves et al., 2013).

Despite the stress reactions observed in the sample, there was no predominance of moderate and severe levels of anxiety and depression, that is, as a group, most caregivers of children and adolescents with sickle cell anemia, demonstrated a good emotional adjustment, regarding these variables. This finding has also been verified in other disease contexts, especially cancer (Okado, Tillery, Sharp, Long, \& Phipps, 2016). There seems to be a tendency, on the part of families, of a more stable adjustment to the demands of the disease and treatment, over time (Okado et al., 2016). The families of children with sickle cell anemia in this study seem to follow the same adjustment path observed in childhood cancer, in which some families have indicators of poor adjustment, while so many others have good adjustment (Okado et al., 2016).

At this point, the contribution of this study to the understanding of the relationships between the variables involved in the process of psychological adaptation to a chronic disease in the family is highlighted. After knowing the indicators of the psychological impact of sickle cell anemia on caregivers and finding that psychological adjustment can be observed in many families, the researchers of this study sought to verify the determinants of this adaptive outcome. This study confirmed the hypothesis that the adaptation process variables, especially coping, act as predictors of anxiety and depression indicators in family caregivers of children and adolescents with sickle cell anemia. It was possible to identify that the use of primary control coping strategies decreases scores related to depression, and the use of coping with involuntary engagement predicts the increase of depression and anxiety of caregivers.

These results confirm the model's capacity based on the perceived controllability of the stressor, described by Compas et al. (2012), to explain the relationship between the variables related to the child's adaptation process to the disease. It is understood, therefore, that adaptive coping practices can act as a protection to emotional variables, reducing levels of anxiety and parental depression, and still acting as a protective factor for child and adolescent development (Pai et al., 2007), being necessary that intervention programs, focused on the coping of caregivers, are implemented in health institutions (Shashine et al., 2014).

Some limitations can be described in the study. The analysis of the adaptation process to the disease considered only emotional indicators of one of the caregivers, that is, one of the members of the family system. It is considered that further studies may include measures for more than one family member, besides the child's own variables. In addition, data discussion was restricted, regarding studies carried out in the Brazilian society, since most of the publications come from North American studies. This fact is, on the one hand, a limitation, but on the other, it indicates a contribution to reduce the gap in the investigation of the socioemotional dimension in the context of sickle cell anemia (Rodrigues et al., 2010).

The findings of this study are in line with the statements about the need to include the family in the medical care of patients with chronic diseases, as an active agent. In this sense, health care must be based both on the needs of patients and their families (Figueiró \& Ribeiro, 2017; Rodrigues et al., 2010).

It is concluded that the trajectory of children and adolescents with sickle cell anemia requires attention from caregivers, monitoring psychological variables that can be affected by stressful events related to the disease and the treatment. Special attention is given to coping, which should be the focus of intervention proposals with this population, since it has been shown to be a predictor of anxiety and depression indicators.

\section{Contributors}

F. R. CAPRINI was responsible for the conception, design, analysis, and data interpretation. A. B. MOTTA contributed to all stages of it article construction, as well as the review and approval of the final version. 


\section{References}

Abidin, R. R. (1992). The determinants of parenting behavior. Journal of Clinical Child Psychology, 21, 407-412. http:// dx.doi.org/10.1207/s15374424jccp2104_12

Alves, D. F. S., Guirardello, E. B., \& Kurashima, A. Y. (2013). Estresse relacionado ao cuidado: o impacto do câncer infantil na vida dos pais. Revista Latino-Americana de Enfermagem, 21(1), 1-7. http://dx.doi.org/10.1590/S0104-1 1692013000100010

Associação Brasileira de Empresas de Pesquisa. (2013). Critério de classificação econômica Brasil. São Paulo: Autor. Recuperado de http:www.abep.org

Baptista, M. N. (2007). Inventário de percepção de suporte familiar (IPSF): estudo componencial em duas configurações. Psicologia: Ciência e Profissão, 27(3), 496-509. http://dx.doi.org/10.1590/S1414-98932007000300010

Brown, R. T., Lambert, R., Devine, D., Baldwin, K., Casey, R., Doepke, K., ... Eckman, J. (2000). Risk-resistance adaptation model for caregivers and their children with sickle cell syndromes. Annals of Behavioral Medicine, 22, 158-169. http:// dx.doi.org/10.1007/BF02895780

Campelo, L. M. N., Oliveira, N. F., Magalhães, J. M., Julião, A. M. S., Amorim, F. C. M., \& Coelho, M. C. V. S. (2018). A dor da criança com doença falciforme: abordagem do enfermeiro. Revista Brasileira de Enfermagem, 71(3), 1381-1387. http://dx.doi.org/10.1590/0034-7167-2016-0648

Caprini, F. R. (2019). Avaliação e intervenção psicossocial em cuidadores familiares de crianças com anemia falciforme (Tese de doutorado não-publicada). Universidade Federal do Espírito Santo, Vitória, ES, Brasil.

Compas, B. E., Jaser, S. S., Dunn, M. J., \& Rodriguez, E. M. (2012). Coping with chronic illness in childhood and adolescence. Annual Reviews Clinical Psychology, 27(8), 455-480. https://doi.org/10.1146/annurev-clinpsy-032511-143108

Connor-Smith, J. K., Compas, B. E., Wadsworth, M. E., Thomsen, A. H., \& Saltzman, H. (2000). Responses to stress in adolescence: measurement of coping and involuntary stress responses. Journal of Counseling and Clinical Psychology, 68(6), 976-992. https://doi.org/10.1037/0022-006X.68.6.976

Cunha, J. A. (2001). Manual da versão em português das Escalas de Beck. São Paulo: Casa do Psicólogo.

Figueiredo, S. V., Moreira, T. M. M., Mota, C. S., Oliveira, R. S., \& Gomes, I. L. V. (2019). Elaboração e validação de caderneta de orientação em saúde para familiares de crianças com doença falciforme. Escola Ana Nery, 23(1), 1-10. http://dx.doi.org/10.1590/2177-9465-EAN-2018-0231

Figueiró, A. V. M., \& Ribei,5Monti, J. D., Winning, A., Watson, K. H., Williams, E. K., Gerhardt, C. A., Compas, B. E., \& Vannatta, K. (2017). Maternal and paternal influences on children's coping with cancer-related stress. Journal of Child and Family Studies, 26(7), 2016-2025. https://doi.org/10.1007/s10826-017-0711-y

Gomes, M. V., Xavier, A. S. G., Carvalho, E. S. S, Cordeiro, R. C., Ferreira, S. L., \& Morbeck, A. D. (2019). "À espera de um milagre": espiritualidade/religiosidade no enfrentamento da doença falciforme. Revista Brasileira de Enfermagem, 74(6), 1632-1639. http://dx.doi.org/10.1590/0034-7167-2018-0635

Jesus, A. C. S., Konstantyner, T., Lobo, I. K. V., \& Braga, J. A. P. (2018). Características socioeconômicas e nutricionais de crianças e adolescentes com anemia falciforme: uma revisão sistemática. Revista Paulista de Pediatria, 26(4), 491-499. http://dx.doi.org/10.1590/1984-0462/;2018;36;4;00010

Kazak, A. E., Cant, C., Jensen, M. M., McSherry, M., Rourke, M. T., Hwang W., ... Lange, B. C. (2003). Identifying psychosocial risk indicative of subsequent resource use in families of newly diagnosed oncology patients. Journal of Clinical Oncology, 21, 3220-3225. http://dx.doi.org/10.1200/JCO.2003.12.156

Lovejoy, M. C., Graczyk, P. A., O'Hare, E., \& Neuman, G. (2000). Maternal depression and parenting behavior: a meta-analytic review. Clinical Psychology Review, 20(5), 561-592. https://doi.org/10.1016/S0272-7358(98)00100-7

McGann P. T. (2014). Sickle cell anemia: an underappreciated and unaddressed contributor to global childhood mortality. The Journal of Pediatrics, 165(1), 18-22. https://doi.org/10.1016/j.jpeds.2014.01.070

Ministério da Saúde (Brasil). (2015). Doença falciforme: diretrizes básicas da linha de cuidado. Brasília: Autor. Recuperado de http://bvsms.saude.gov.br/bvs/publicacoes/doenca_falciforme_diretrizes_basicas_linha_cuidado.pdf

Miranda, F. P., \& Brito, M. B. (2016). Assistência multidisciplinar ao paciente com anemia falciforme na internação de crises álgicas: uma revisão integrativa. Revista Enfermagem Contemporânea, 5(1), 143-150. https://doi.org/10.17267/2317-3 378rec.v5i1.830

Monti, J. D., Winning, A., Watson, K. H., Williams, E. K., Gerhardt, C. A., Compas, B. E., \& Vannatta, K. (2017). Maternal and paternal influences on children's coping with cancer-related stress. Journal of Child and Family Studies, 26(7), 2016-2025. https://doi.org/10.1007/s10826-017-0711-y 
Oliveira, C. G. T., Enumo, S. R. F., \& Paula, K. M. P. (2017). A psychological intervention proposal on coping with pain for children with Sickle Cell Disease. Estudos de Psicologia (Campinas), 34(3), 355-366. http://dx.doi.org/10.1590/1982-0 2752017000300004

Okado, Y., Tillery, R., Sharp, K. H., Long, A. M., \& Phipps, S. (2016). Effects of time since diagnosis on the association between parent and child distress in families with pediatric cancer. Journal of Child Health Care, 45(3), $303-322$. https://doi.org/10.1080/02739615.2014.996883

Pai, A. L. H., Greenley, R., Neff Lewandowski, A., Drotar, D., Youngman, E., \& Peterson, C. C. (2007). A meta-analytic review of the influence of pediatric cancer on parent and family functioning. Journal of Family Psychology, 21(3), 407-415. https://doi.org/10.1037/0893-3200.21.3.331

Prussien, K. V., Baun, M. R., Yarboi, J., Bemis, H., McNally, C., ... Comas, B. E. (2018). Cognitive function, coping, and depressive symptoms in children and adolescents with Sickle Cell Disease. Journal of Pediatric Psychology, 43(5), 543-55. https://doi.org/10.1093/jpepsy/jsx141

Reis, F. M. S., Branco, R. R. O. C., Conceição, A. M., Trajano, L. P. B., Vieira, J. F. P. N., Ferreira, P. R. B., \& Araújo, E. J. F. (2018). Incidência de hemoglobinas variantes em neonatos assistidos por um laboratório de saúde pública. Einstein (São Paulo), 16(2), 1-7. https://doi.org/10.1590/S1679-45082018A04150

Rodrigues, C. C. M., Araújo, I. E. M., \& Melo, L. L. (2010) A família da criança com doença falciforme e a equipe enfermagem: revisão crítica. Revista Brasileira de Hematologia e Hemoterapia, 32(3), 257-264. http://dx.doi. org/10.1590/S1516-84842010005000079.

Rodriguez, E. M., Murphy, L., Vannatta, K., Gerhardt, C. A., Young-Saleme, T., Saylor, M., ... Compas, B. E. (2016). Maternal coping and depressive symptoms as predictors of mother-child communication about a child's cancer. Journal of Pediatric Psychology, 41(3), 329-339. https://doi.org/10.1093/jpepsy/jsv106

Sabino, M. F., \& Gradella, D. B. T. (2016). Perfil epidemiológico de pacientes internados por doença falciforme no estado do Espírito Santo, Brasil (2001-2010). Revista Brasileira de Pesquisa em Saúde, 18(2), 35-41. https://doi.org/10.21722/ rbps.v18i2.15082

Santos, I. N., Damião, J. J., Fonseca, M. J. M., Rodrigues, C. S. C., \& Aguiar, O. B. (2019). Insegurança alimentar e apoio social em famílias de crianças com doença falciforme. Jornal de Pediatria, 95(3), 306-313. http://dx.doi.org/10.1016/j. jped.2018.01.005

Sarat, C. N. F., Ferraz, M. B., Ferreira, M. A., Jr., Corrêa Filho, R. A., Souza, A. S., Cardoso, A. I. Q., \& Ivo, M. L. (2019). Prevalência da doença falciforme em adultos com diagnóstico tardio. Acta Paulista de Enfermagem, 32(2), $202-209$. http://dx.doi.org/10.1590/1982-0194201900028

Shashine, R., Badr, L. K., Karam, D., \& Abboud, M. (2014). Educational intervention to improve the health outcomes of children with sickle cell disease. Journal of Pediatric Health Care, 29(1), 54-60. https://doi.org/10.1016/j. pedhc.2014.06.007

Streisand, R., Braniecki, S., Tercyak, K. P., \& Kazak, A. E. (2001). Childhood illness-related parenting stress: the pediatric inventory for parents. Journal of Pediatric Psychology, 26(3), 155-62. https://doi.org/10.1093/jpepsy/26.3.155

Thompson, R. J., Jr., Gil, K. M., Burbach, D. A., Keith, B. R., \& Kinney, T. R. (1993). Psychological adjustment of mothers of children and adolescents with sickle cell disease: the role of stress, coping methods and family functioning. Journal of Pediatric Psychology, 18, 549-559. https://doi.org/10.1093/jpepsy/18.5.549

Wadsworth, M. E., Rieckmann, T., Benson, M. A., \& Compas, B. (2004). Coping and responses to stress in Navajo adolescents: psychometric properties of the responses to stress questionnaire. Journal of Community Psychology, 32(4), 391-411. https://doi.org/10.1002/jcop.20008

Wallander, J. L., Varni, J. W., Babani, L., Banis, H. T., Haan, C. B., \& Wilcox, K. T. (1989). Disability parameters, chronic strain, and adaptation of physically handicapped children and their mothers. Journal of Pediatric Psychology, 24, $23-42$. https://doi.org/10.1093/jpepsy/14.1.23

Received: December 6, 2019

Final version: May 7, 2020

Approved: June 3, 2020 